\title{
Power Generation Enhancement by Utilizing Plant Photosynthate in Microbial Fuel Cell Coupled Constructed Wetland System
}

\author{
Shentan Liu, ${ }^{1}$ Hailiang Song, ${ }^{1}$ Xianning Li, ${ }^{1}$ and Fei Yang ${ }^{2}$ \\ ${ }^{1}$ School of Energy and Environment, Southeast University, Nanjing 210096, China \\ ${ }^{2}$ School of Public Health, Southeast University, Nanjing 210096, China \\ Correspondence should be addressed to Xianning Li; lxn@seu.edu.cn
}

Received 27 June 2013; Accepted 31 August 2013

Academic Editor: Manickavachagam Muruganandham

Copyright ( $\odot 2013$ Shentan Liu et al. This is an open access article distributed under the Creative Commons Attribution License, which permits unrestricted use, distribution, and reproduction in any medium, provided the original work is properly cited.

In the present study, a new technology that coupled constructed wetland (CW) with microbial fuel cell (MFC) (CW-MFC) was developed to convert solar energy into electricity on the principles of photosynthetic MFC by utilizing root exudates of Ipomoea aquatica as part of fuel. The maximum power density of $12.42 \mathrm{~mW} \mathrm{~m}^{-2}$ produced from the CW-MFC planted with Ipomoea aquatica was $142 \%$ higher than that of $5.13 \mathrm{~mW} \mathrm{~m}^{-2}$ obtained from the unplanted CW-MFC. The maximum power output for the planted CW-MFC could be divided into two parts: the maximum power yield from $\mathrm{COD}_{R}$ in the water body was $66.05 \mathrm{KJ} \mathrm{Kg}^{-1} \mathrm{COD}_{R}$, and the maximum power transformation from plant photosynthesis was $2.31 \mathrm{GJ} \mathrm{ha}^{-1} \mathrm{year}^{-1}$. The average COD removal efficiencies were 92.1\% and $94.8 \%$ in the unplanted CW-MFC and planted CW-MFC, respectively; the average TN removal efficiencies amounted to $54.4 \%$ and $90.8 \%$ in the unplanted CW-MFC and planted CW-MFC. This research demonstrates that planting Ipomoea aquatica in the CW-MFC achieved a higher power density and nutrient removal of nitrogen simultaneously.

\section{Introduction}

A microbial fuel cell (MFC) is a bioelectrochemical system making use of biocatalyst for converting chemical energy into electricity, and it has been considered as one of the promising and sustainable technologies for power generation as well as waste management [1-3]; especially, in the past decade, there has been a remarkable promotion of MFC performance through a large variety of methods, including advancement of fuel cell configuration $[4,5]$, selection and modification of electrode material [6-8], and adoption of cheap proton exchange membrane with high conductivity efficiency $[9,10]$. Besides, novel technologies in generating power by integrating photosynthesis with microbial fuel cells (photosynthetic MFC) have been researched and significant progress has been made [11-14]. The photosynthetic MFC operates to generate sufficient electric current from sunlight with either electrocatalysts or heterotrophic bacteria on the anode to convert photosynthetic products indirectly [15], and the photosynthesis could be carried out by plants, algae, or some photosynthetic bacteria. The photosynthetic MFC can produce electricity without the external input of exogenous organics or nutrients, but it is often restricted by sunlight and its power density is still too low for practical applications.

Wetland treatment of wastewater has been widely practiced in several countries for many years due to its easy maintenance, low cost, and good self-purification capacity; moreover, it provides great quantities of biomass production by photosynthesis [16]. A well-designed microbial fuel cell inside a constructed wetland system may combine the advantages of the photosynthesis of wetland plants and electricity generation of electroactive microorganisms to transform solar energy into electricity. The first lab-scale CW-MFC was designed and operated to evaluate the effect of configuration on power production [17], and it also showed good wastewater treatment effect with simultaneous power generation. As the constructed wetland has the ability of degradation of refractory organic matter, the CW-MFC system had great advantages in treating dye containing wastewater [18]. 
The concept of CW-MFC is based on constructed wetland and plant MFC (one form of photosynthetic MFC), of which all contain plants. The role of plants is important in the CW-MFC system, including their role in excreting oxygen and organic matter into the rhizosphere [19], supporting a wide range of microbes and providing a surface for bacterial attachment [20]. These unique characteristics may make the CW-MFC system an ideal approach to generate electricity at sites and reduce globing warming as they can decrease methane emissions. However, the effect of plant photosynthesis and plant rhizosphere microorganisms on the power enhancement for the CW-MFC has not been studied fully yet.

In this study, we built a single-chamber, membranefree, continuously feeding upflow microbial fuel cell coupled with constructed wetland, in which the cathode is located in overlying water to use oxygen from air for reduction reactions, and the anode is submerged in a support matrix near the rhizosphere to obtain organic substrates in the influent or deprived from wetland plants root as fuel. The aim of this study was to evaluate whether or not the wetland plant (Ipomoea aquatica) can improve power generation in a CWMFC system and to explore the bacterial population in the electrode biofilm in response to MFC performance. Meanwhile, investigations of the removal efficiencies of chemical oxygen demand (COD) and total nitrogen (TN) were carried out.

\section{Experimental}

2.1. CW-MFC Construction. As schematically shown in Figure 1, two CW-MFC reactors were constructed in the same way using a polycarbonate plastic cylinder $(30 \mathrm{~cm}$ in diameter and $50 \mathrm{~cm}$ in height). The bottom $20 \mathrm{~cm}$ was support matrix composed of gravel (gravel diameter 3-6 mm), and then upwards it consisted of anode, support matrix $(20 \mathrm{~cm}$ gravel), and cathode. The anode was constructed from $10 \mathrm{~cm}$ thick granular activated carbon (GAC, a diameter of 3-5 mm, the specific area of $500-900 \mathrm{~m}^{2} \mathrm{~g}^{-1}$ and the filling density of $\left.0.45-0.55 \mathrm{~g} \mathrm{~cm}^{-3}\right)$. GAC was pretreated by soaking in $1 \mathrm{M}$ $\mathrm{NaOH}$ and $1 \mathrm{M} \mathrm{HCl}$ to eliminate possible oil stain and metal ion contamination, respectively. The cathode was made from stainless steel mesh (a diameter of $25 \mathrm{~cm}$, thickness of $0.3 \mathrm{~cm}$, 12 mesh) buried in $2 \mathrm{~cm}$ thick layer of activated carbon particle. The electrode spacing was $25 \mathrm{~cm}$ (center of the anode to the face of the cathode). Electrodes were connected to a circuit using titanium wires across an external resistance of $1000 \Omega$, and epoxy was used to seal metals exposed to the solution. Nine adult plants of Ipomoea aquatica were planted through the upper layer of one CW-MFC device (planting density about 32 plants $\mathrm{m}^{-2}$ ), and the other CW-MFC was a control with no plants. The volume of the whole container was $35.3 \mathrm{~L}$ with a total liquid volume of $12.4 \mathrm{~L}$.

2.2. $C W-M F C$ Operation. The CW-MFCs were inoculated with the anaerobic sludge from a wastewater treatment plant located in Jiangning Development Zone (Nanjing, China) and operated by continuous feeding at a flow

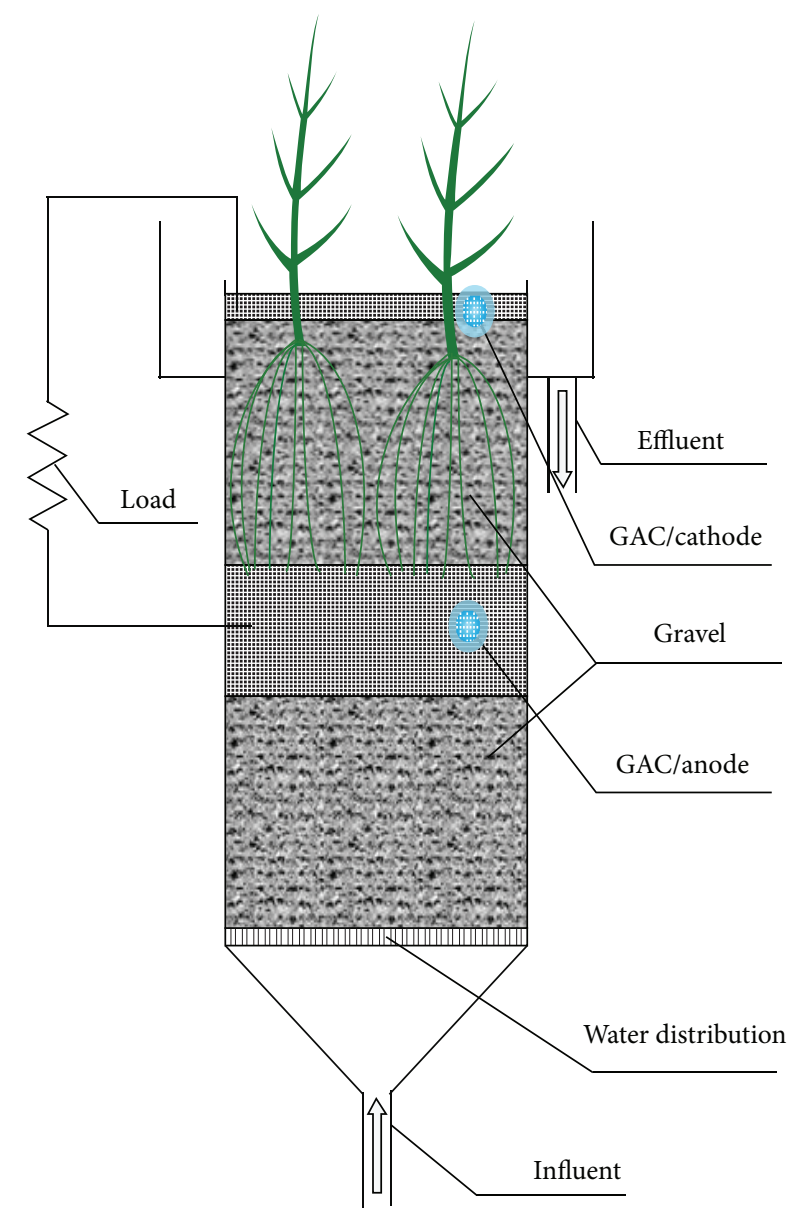

FIGURE 1: Schematic of the CW-MFCs used in the experiment.

rate of $4.31 \mathrm{~mL} \mathrm{~min}^{-1}$ corresponding to a hydraulic retention time (HRT) of $2 \mathrm{~d}$. The feed solution consisted

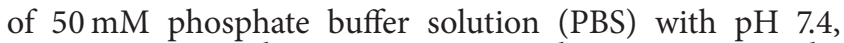
glucose $\left(0.20 \mathrm{~g} \mathrm{~L}^{-1}\right), \mathrm{NH}_{4} \mathrm{Cl}\left(0.15 \mathrm{~g} \mathrm{~L}^{-1}\right), \mathrm{KCl}\left(0.13 \mathrm{~g} \mathrm{~L}^{-1}\right)$, $\mathrm{NaHCO}_{3}\left(3.13 \mathrm{gL}^{-1}\right)$, and $1 \mathrm{mLL}^{-1}$ trace essential elements solution (contained per liter: $5.6 \mathrm{~g}\left(\mathrm{NH}_{4}\right)_{2} \mathrm{SO}_{4}, 2 \mathrm{~g}$ $\mathrm{MgSO}_{4} \cdot 7 \mathrm{H}_{2} \mathrm{O}, 200 \mathrm{mg} \mathrm{MnSO}_{4} \cdot \mathrm{H}_{2} \mathrm{O}, 3 \mathrm{mg} \mathrm{H} \mathrm{H}_{3} \mathrm{BO}_{3}, 2.4 \mathrm{mg}$ $\mathrm{CoCl}_{2} \cdot 6 \mathrm{H}_{2} \mathrm{O}, 1 \mathrm{mg} \mathrm{CuCl}_{2} \cdot 2 \mathrm{H}_{2} \mathrm{O}, 2 \mathrm{mg} \mathrm{NiCl} \cdot 6 \mathrm{H}_{2} \mathrm{O}, 5 \mathrm{mg}$ $\mathrm{ZnCl}_{2}, 10 \mathrm{mg} \mathrm{FeCl} \cdot 6 \mathrm{H}_{2} \mathrm{O}$, and $0.4 \mathrm{mg} \mathrm{Na} \mathrm{MoO}_{4} \cdot 2 \mathrm{H}_{2} \mathrm{O}$ ). All experiments were carried out in a 12:12-h light/dark cycle at $26 \pm 2^{\circ} \mathrm{C}$ under greenhouse conditions. The ambient light was provided by artificial illumination using (light-emitting diode LED) Grow Lights (14 W, GC-ZW225S-P, Gechuang Electronics Co., Ltd, Shenzhen, China), and the average light intensity was 1000 lux during the light phase.

2.3. Fluorescent In Situ Hybridization (FISH). FISH analysis was applied to investigate the quantity of microorganisms on the anode and cathode in our study. Granular activated carbon with attached biofilm (wet weight of $0.5 \mathrm{~g}$ ) was multisampled (parallel samples) and suspended in $5 \mathrm{~mL}$ sterile deionized water, and microorganism cells were detached from the GAC and uniformly dispersed in the solution with ultra-sonic oscillations treatment. About $0.5 \mathrm{~mL}$ supernatant 
TABLE 1: Probe name and probe sequence used for FISH analysis.

\begin{tabular}{lccc}
\hline Probe & Target microflora & Probe sequence & References \\
\hline EUB338 & Bacteria & GCTGCCTCCCGTAGGAGT & {$[21,22]$} \\
GEO2 & Geobacter sulfurreducens & GAAGACAGGAGGCCCGAAA & {$[23]$} \\
HGEO2-1 & Helper probes for GEO2 & GTCCCCCCCTTTTCCCGCAAGA & {$[23]$} \\
HGEO2-2 & Helper probes for GEO2 & CTAATGGTACGCGGACTCATCC & {$[23]$} \\
BET42a & Betaproteobacteria & GCCTTCCCACTTCGTTT & {$[24]$} \\
\hline
\end{tabular}

after ultrasonic oscillations was shifted and suspended in phosphate-buffered saline solution (PBS, $\mathrm{pH}$ 7.4) consisting of $8 \mathrm{~g} \mathrm{~L}^{-1} \mathrm{NaCl}, 0.2 \mathrm{gL}^{-1} \mathrm{KCl}, 1.44 \mathrm{gL}^{-1} \mathrm{Na}_{2} \mathrm{HPO}_{4}$, and $0.24 \mathrm{~g} \mathrm{~L}^{-1} \mathrm{~K}_{2} \mathrm{HPO}_{4}$ in distilled water. Then the samples were fixed with $4 \%$ paraformaldehyde (in PBS) at $4^{\circ} \mathrm{C}$ for $24 \mathrm{~h}$. The fixed samples were washed twice with PBS, and suspended in a solution of $50 \%$ PBS, and $50 \%$ ethanol and stored at $-20^{\circ} \mathrm{C}$. For FISH, $10 \mu \mathrm{L}$ of the fixed sample was applied on a glass slide dried for $2 \mathrm{~h}$ at $37^{\circ} \mathrm{C}$ and subsequently dehydrated with ethanol at 50, 80, and $96 \%(\mathrm{v} / \mathrm{v}$, in $10 \mathrm{mM}$ Tris-HCl, $\mathrm{pH} 7.5)$ during $3 \mathrm{~min}$ at each concentration. To start hybridization, $24 \mu \mathrm{L}$ of hybridization buffer and $1 \mu \mathrm{L}$ of fluorescently labeled probe $\left(50 \mathrm{ng} \mathrm{mL}^{-1}\right)$ were added. The hybridization was conducted for $5 \mathrm{~h}$ at $46^{\circ} \mathrm{C}$ in a humidified chamber. Slides were then washed in a buffer solution $(60 \mathrm{mM} \mathrm{NaCl}, 20 \mathrm{mM}$ Tris$\mathrm{HCl}, \mathrm{pH} 8.0,0.1 \% \mathrm{SDS}$ ) at $45^{\circ} \mathrm{C}$ for $20 \mathrm{~min}$.

In the FISH procedure, target microflora and oligonucleotide probes used were shown in Table 1. Hereinto, Geobacter sulfurreducens and Betaproteobacteria have been evaluated for the potential for current production. Microscopy was performed on an Olympus BX50 microscope, equipped with filters HQ-CY3 (Analysentechnik AG, Tübingen, Germany). The bacterial number on each image was counted, and then the bacterial density $\left(D_{b}\right)$ of each biofilm cathode was calculated from the following equation:

$$
D_{b}=\frac{1000 N S_{1}}{M S_{2}}
$$

where $S_{1}, S_{2}$, and $M$ represent the coating area, the image area, and the sample weight $(\mathrm{g})$, respectively, and $N$ is the average bacterial number on each image (cells). All cell density data shown in this paper were statistical average values.

2.4. Measurement and Analysis. The cell voltage was recorded every $30 \mathrm{~min}$ by a data acquisition system (USB120816, Hytek Automation, Inc., Shanghai, China). The cell potentials were measured against a saturated $\mathrm{Ag} / \mathrm{AgCl}(\mathrm{S})$ electrode. Polarization curves were obtained in the daytime (high peak voltage) by varying the external resistor over a range from $5 \Omega$ to $10^{5} \Omega\left(10^{5}, 4000,3000,2000,1000,800,600,400,200,100\right.$, $75,50,25,10$, and $5 \Omega$ ) to monitor the output voltage. The current (i) was calculated from Ohm's law as shown in (2), and the power density ( $P$, area power density) was calculated as shown in (3), where $E$ is the voltage, $R$ is the external resistance, and $A$ is the anode area. The ohmic resistance $\left(R_{\Omega}\right)$ of each system was determined using the current interrupt technique [25], and $R_{\Omega}$ was calculated as shown in (4).
$E_{R}$ is a steep potential rise when the current is interrupted, and $E_{\mathrm{OCV}}$ is the open circuit voltage:

$$
\begin{gathered}
i=\frac{E}{R}, \\
P=\frac{E^{2}}{R A}, \\
R_{\Omega}=\frac{E_{R}}{i}=\frac{\left(E_{\mathrm{OCV}}-E\right) R}{E} .
\end{gathered}
$$

Chemical oxygen demand (COD), ammonia nitrogen $\left(\mathrm{NH}_{4}{ }^{+}-\mathrm{N}\right)$, nitrite nitrogen $\left(\mathrm{NO}_{2}{ }^{-}-\mathrm{N}\right)$, and nitrate nitrogen $\left(\mathrm{NO}_{3}{ }^{-}-\mathrm{N}\right)$ were performed in accordance with the Standard Methods of American Public Health Association (APHA, 1998), and all the samples for chemical analysis were filtered through a $0.45 \mu \mathrm{m}$ pore diameter syringe filter to remove particles. Total nitrogen (TN) concentration was calculated as the sum of $\mathrm{NH}_{4}^{+}-\mathrm{N}, \mathrm{NO}_{2}^{-}-\mathrm{N}$, and $\mathrm{NO}_{3}{ }^{-}-\mathrm{N}$. Dissolved oxygen (DO) concentration was measured in situ by the DO probe (ORION 3 STAR, Thermo Co., USA). All measurements were made at least three times and the average values with standard deviations are presented in the figures.

Specific power yield (SPY) was obtained by dividing power generated $\left(P_{V}\right.$, volume power density) with the substrate (COD) removed as shown in (5) [26], where $V$ is the total liquid volume of the $\mathrm{CW}-\mathrm{MFC}, \mathrm{COD}_{\text {in }}$ the influent $\mathrm{COD}$ and $\mathrm{COD}_{\text {out }}$ the effluent COD. The power yield (PY) was calculated as shown in (6), and it implicates the power output per kilogram of organic substrate $\left(\mathrm{COD}_{R}\right)$ in the water body:

$$
\begin{aligned}
\mathrm{SPY}=\frac{P_{V}}{\mathrm{COD}_{R}} & =\frac{E^{2}}{\left(\mathrm{COD}_{\text {in }}-\mathrm{COD}_{\text {out }}\right) R V}, \\
\mathrm{PY} & =\mathrm{SPY} \times \mathrm{HRT} .
\end{aligned}
$$

\section{Results}

3.1. Power Output. The two CW-MFCs were operated for more than 1 month to obtain a stable performance before the determination of cell voltage. Figure 2(a) shows voltage outputs from the planted CW-MFC and unplanted CW-MFC electricity-generating systems from May 3 to June 10. At the initial stage (1-8 days), the trough voltages of the planted CW-MFC $(0.51-0.53 \mathrm{~V})$ were close to the mean voltage of the unplanted CW-MFC $(0.50 \mathrm{~V})$. As Ipomoea aquatica was adapted to the experimental environment, the peak and trough voltages of the planted CW-MFC increased gradually (8-26 days) and remained stable (26-40 days). 


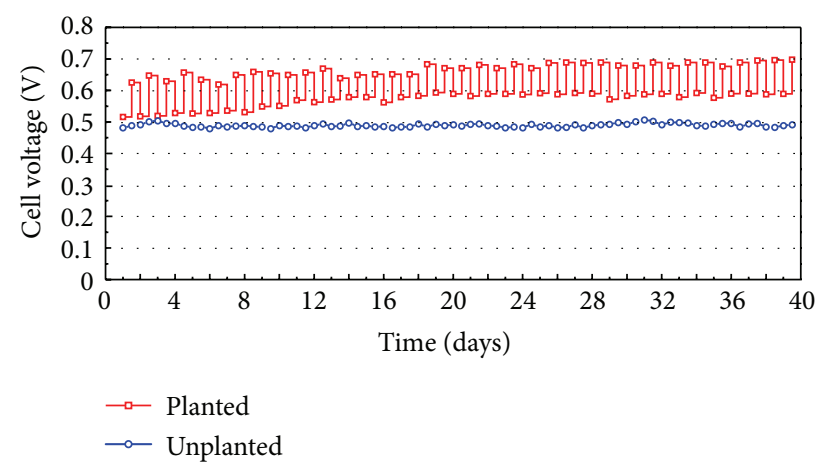

(a)

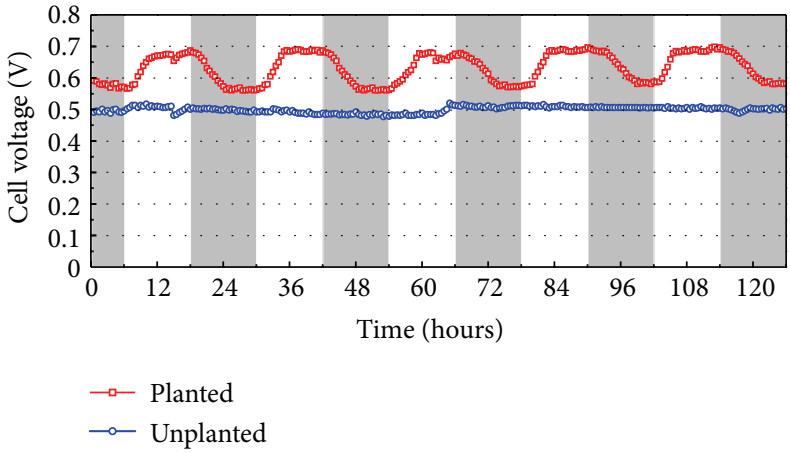

(b)

FIGURE 2: Continuous records of voltage with a fixed external load of $1000 \Omega$ for the planted CW-MFC and unplanted CW-MFC. (a) A daily record of voltages at 0:00 (night through time) and 12:00 (day peak time) from May 3 to June 10; (b) half-hourly records of voltages from June 12 to June 16.

As shown in Figure 2(b), the voltage for the planted CWMFC was characterized by diurnal oscillations with clear fluctuations, but no such circadian oscillation was observed for the unplanted CW-MFC. As temperatures were relatively stable throughout the experiments, the observation implied that the cyclical fluctuation of voltage for the planted CWMFC was closely related to the sunlight. From June 12 to June 16 , the electric output was stable, and the average voltages in the planted CW-MFC and unplanted CW-MFC were 0.64 and $0.49 \mathrm{~V}$, respectively. Therefore, it was calculated that the average power outputs for the planted CW-MFC and unplanted CW-MFC were 0.129 and $0.076 \mathrm{GJ} \mathrm{ha}^{-1}$ year $^{-1}$, respectively. Taking into account the consistency of the influent condition and the culture environment in the two CW-MFCs, the power output about $0.053 \mathrm{GJ} \mathrm{ha}^{-1}$ year $^{-1}$ was generated from plant photosynthetic products in the planted CW-MFC.

3.2. Fuel Cell Behavior. The performance of the planted CWMFC was depicted and compared with the unplanted CWMFC in terms of power density curves and polarization curves. It can be seen from Figure 3 that planting Ipomoea aquatica in CW-MFC effectively enhanced the electricity generation. The open circuit voltages of the planted CW-MFC and unplanted CW-MFC were 0.74 and $0.62 \mathrm{~V}$, respectively, and the maximum power density of the planted CW-MFC was $12.42 \mathrm{~mW} \mathrm{~m}^{-2}, 2$-folds more than that of the unplanted CW-MFC $\left(5.13 \mathrm{~mW} \mathrm{~m}^{-2}\right)$. Maximum power outputs of the planted CW-MFC and unplanted CW-MFC were 3.92 and $1.61 \mathrm{GJ} \mathrm{ha}^{-1}$ year $^{-1}$, respectively. According to (3), the internal resistances of the planted CW-MFC and unplanted CW-MFC were 156 and $256 \Omega$, respectively.

3.3. Relation of Electrode Potentials and Cell Density on the Electrode. It was demonstrated that the catalytic activity of the electrode positively correlates with biomass [27]. To verify the hypothetical inference, electrode potentials and cell densities in various GAC electrodes zone were determined (Figure 4). The average cathode potential $(299 \mathrm{mV})$ of the planted CW-MFC was higher than that of the unplanted

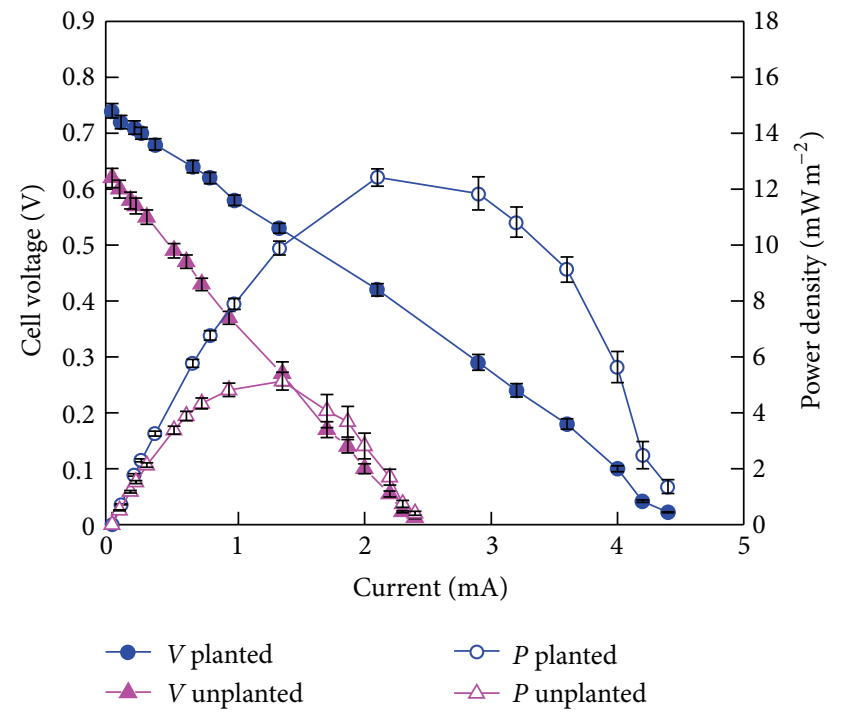

FIgure 3: Polarization curves of the planted CW-MFC and unplanted CW-MFC (solid symbols for the cell voltage and open symbols for the power density).

CW-MFC (202 mV) (Figure 4(a)), and the average anode potential $(-341 \mathrm{mV})$ of the planted CW-MFC was lower than that of the unplanted CW-MFC $(-288 \mathrm{mV})$ (Figure 4(b)). As shown in Figure 4(a), the average bacteria density in cathodic biofilms of the planted CW-MFC $\left(3.85 \pm 0.61 \times 10^{7}\right.$ cells $\mathrm{g}^{-1}$ ) was higher than that of the unplanted CW-MFC $\left(2.43 \pm 0.40 \times 10^{7}\right.$ cells g $\left.^{-1}\right)$. From Figure 4(b), it was clearly observed that cell densities of bacteria, G. sulfurreducens, and Betaproteobacteria in anodic biofilms of the planted CW-MFC $\left(8.66 \pm 1.01 \times 10^{7}\right.$ cells g $^{-1}, 1.22 \pm 0.18 \times 10^{7}$ cells $\mathrm{g}^{-1}$, and $0.91 \pm 0.13 \times 10^{7}$ cells $\mathrm{g}^{-1}$ ) were also higher than that of the unplanted CW-MFC $\left(5.13 \pm 0.86 \times 10^{7}\right.$ cells $\mathrm{g}^{-1}, 0.67 \pm 0.11 \times 10^{7}$ cells $\mathrm{g}^{-1}$, and $0.48 \pm 0.09 \times 10^{7}$ cells $\left.\mathrm{g}^{-1}\right)$. The results indicated that the cathode potential showed a positive correlation with the microbial amount, 


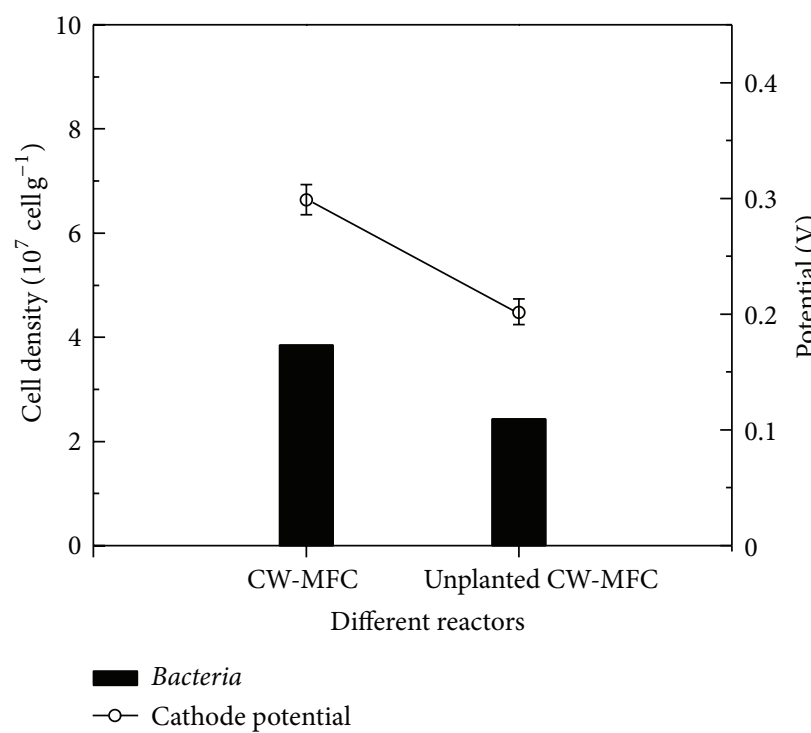

(a)

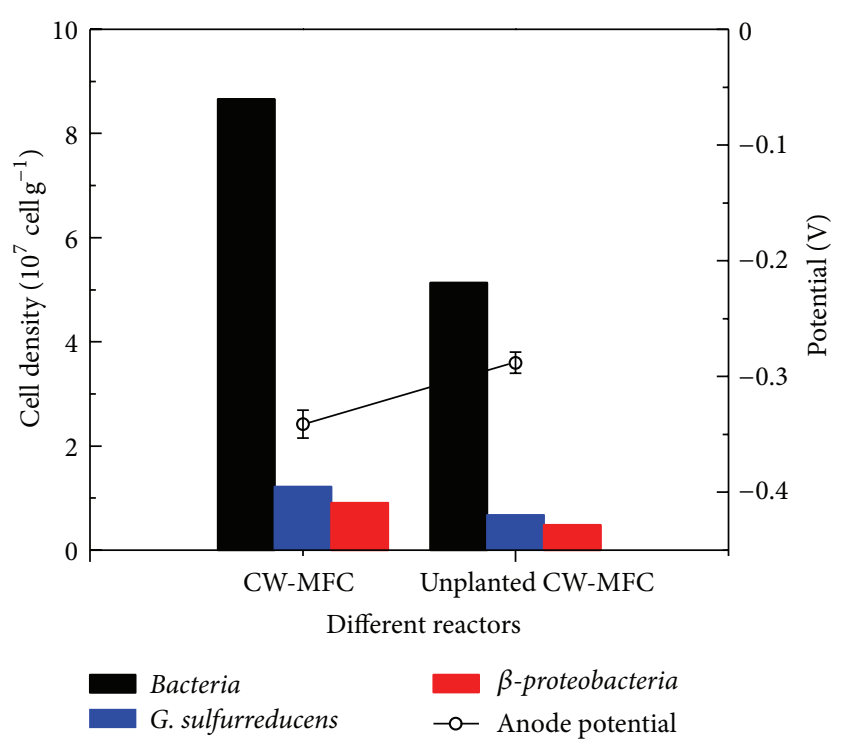

(b)

FIGURE 4: Electrode potential and cell density in electrodes zone for the planted CW-MFC and unplanted CW-MFC: (a) cathode zone and (b) anode zone.

but a negative correlation between the anode potential and microbial amount was observed.

3.4. Waste Treatment. Throughout the experimental stage, the influent chemical oxygen demand (COD) and total nitrogen (TN) reached to the ranges of $193-205 \mathrm{mg} \mathrm{L}^{-1}$ and 31-39 $\mathrm{mg} \mathrm{L}^{-1}$, respectively. More or less, the same COD removal efficiency (planted CW-MFC, 94.8\%; unplanted CW-MFC, 92.1\%) was noticed with both the CWMFCs, but SPY (planted CW-MFC, $0.178 \mathrm{~W} \mathrm{Kg}^{-1} \mathrm{COD}_{R}$; unplanted CW-MFC, $0.107 \mathrm{~W} \mathrm{Kg}^{-1} \mathrm{COD}_{R}$ ) and PY (planted CW-MFC, $30.67 \mathrm{KJ} \mathrm{Kg}^{-1} \mathrm{COD}_{R}$; unplanted CW-MFC, $18.51 \mathrm{KJ} \mathrm{Kg}^{-1} \mathrm{COD}_{R}$ ) showed that the CW-MFC planted with Ipomoea aquatica had higher power productivity efficiency. Unlike the COD removal efficiency, a great difference in the TN removal efficiency (planted CW-MFC, 90.8\%; unplanted CW-MFC, 54.4\%) was observed.

In order to ascertain the reason for the difference of $\mathrm{TN}$ removal efficiencies between the CW-MFCs, the concentration of DO and various forms of nitrogen along the reactor height were investigated in the day time. DO had a " $V$ " type change in both the planted CW-MFC and unplanted CW-MFC (Figure 5). The concentration of DO decreased gradually with the increasement of reactor height till it reached $30 \mathrm{~cm}$ due to the consumption of $\mathrm{O}_{2}$, and then it increased with the increasement of reactor height because of the reoxygenation. The lowest concentrations of DO were in the anode zone, and they were $0.15-0.38 \mathrm{mg} \mathrm{L}^{-1}$ and $0.11-0.31 \mathrm{mg} \mathrm{L}^{-1}$ for the planted CW-MFC and unplanted CW-MFC, respectively. The maximum differentiation of DO occurred at height of $40 \mathrm{~cm}$, and the concentrations of DO were $3.10 \mathrm{mg} \mathrm{L}^{-1}$ and $1.37 \mathrm{mg} \mathrm{L}^{-1}$ for the planted CWMFC and unplanted CW-MFC, respectively. The effluent had

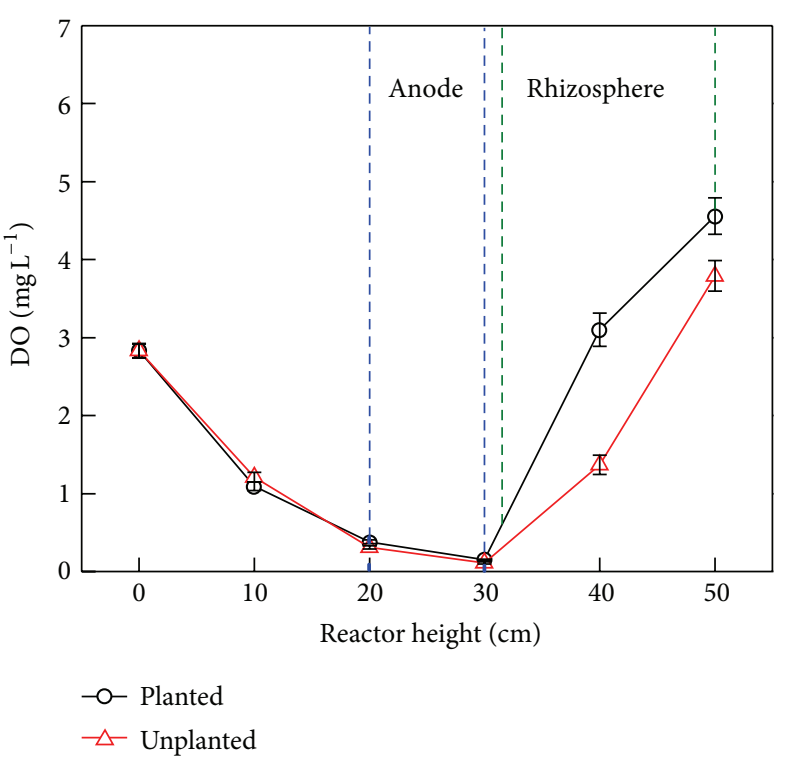

FIGURE 5: The change of DO in the planted CW-MFC and unplanted CW-MFC.

the highest DO of $4.56 \mathrm{mg} \mathrm{L}^{-1}$ and $3.79 \mathrm{mg} \mathrm{L}^{-1}$, respectively, for the planted CW-MFC and unplanted CW-MFC. Furthermore, diurnal variation of $\mathrm{DO}$ in cathode zone for the planted CW-MFC was higher $\left(4.31 \pm 0.18 \mathrm{mg} \mathrm{L}^{-1}\right)$ in the day and lower $\left(3.85 \pm 0.14 \mathrm{mg} \mathrm{L}^{-1}\right)$ at night.

Figures 6 and 7 present the change curves of different forms of nitrogen in the planted CW-MFC and unplanted CW-MFC, respectively, over a period of 13 days. The concentration of TN and $\mathrm{NH}_{4}{ }^{+}-\mathrm{N}$ declined continuously with water flows in both the two CW-MFCs. TN concentrations 


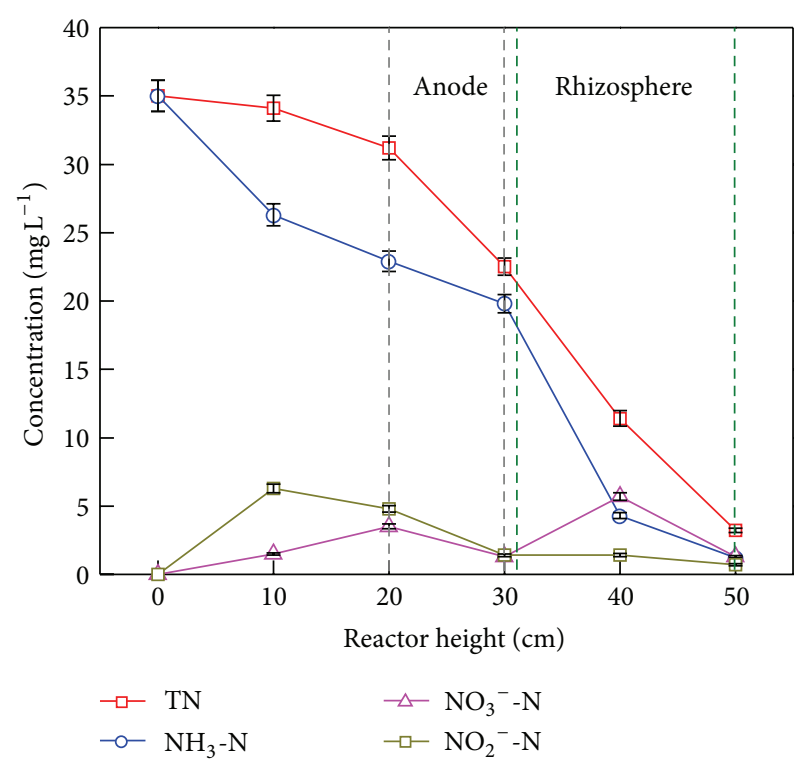

FIGURE 6: The change of different forms of nitrogen in the planted CW-MFC.

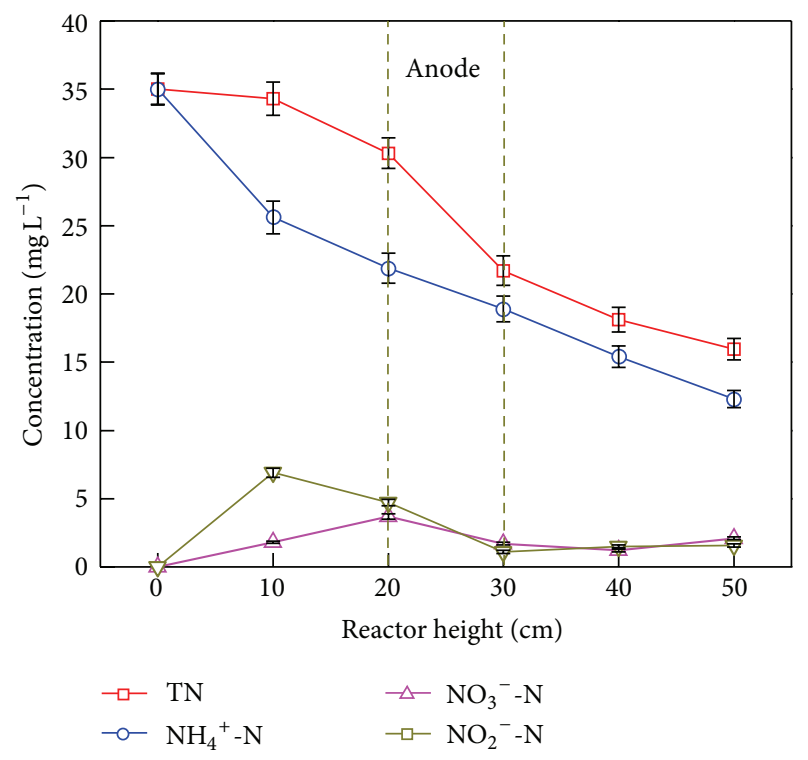

FIGURE 7: The change of different forms of nitrogen in the unplanted CW-MFC.

decreased drastically from $35.00 \mathrm{mg} \mathrm{L}^{-1}$ to $3.22 \mathrm{mg} \mathrm{L}^{-1}$ in the planted CW-MFC, but there was a less decrease from $35.00 \mathrm{mg} \mathrm{L}^{-1}$ to $15.96 \mathrm{mg} \mathrm{L}^{-1}$ in the unplanted CW-MFC. Comparing the change curve of TN for the two CW-MFCs, there were similarities that $\mathrm{TN}$ removal was less in the bottom region $(0-20 \mathrm{~cm})$ and more in the central region $(20-$ $30 \mathrm{~cm}$ ), but there was a great difference in the top region $(30-50 \mathrm{~cm}$ ) that TN removal in the planted CW-MFC (from $22.50 \mathrm{mg} \mathrm{L}^{-1}$ to $3.22 \mathrm{mg} \mathrm{L}^{-1}$ ) was much higher than that in the unplanted CW-MFC (from $21.70 \mathrm{mg} \mathrm{L}^{-1}$ to $15.96 \mathrm{mg} \mathrm{L}^{-1}$ ). The removal efficiencies of $\mathrm{NH}_{4}{ }^{+}-\mathrm{N}$ for the planted CWMFC and unplanted CW-MFC were $96.51 \%$ and $64.86 \%$, respectively. In the planted CW-MFC, there were two sharp descending regions for $\mathrm{NH}_{4}{ }^{+}-\mathrm{N}$ removal: $\mathrm{NH}_{4}{ }^{+}-\mathrm{N}$ decreased from $35.00 \mathrm{mg} \mathrm{L}^{-1}$ to $26.30 \mathrm{mg} \mathrm{L}^{-1}$ at the bottom of $0-10 \mathrm{~cm}$ and from $19.80 \mathrm{mg} \mathrm{L}^{-1}$ to $4.30 \mathrm{mg} \mathrm{L}^{-1}$ at the top of 30 $40 \mathrm{~cm}$. However, in the unplanted CW-MFC, $\mathrm{NH}_{4}{ }^{+}-\mathrm{N}$ only decreased sharply from $35.00 \mathrm{mg} \mathrm{L}^{-1}$ to $25.60 \mathrm{mg} \mathrm{L}^{-1}$ at the bottom of $0-10 \mathrm{~cm}$, and then it began to descend smoothly.

In the planted CW-MFC, the accumulated $\mathrm{NO}_{2}{ }^{-} \mathrm{N}$ concentration gradually increased from $0 \mathrm{mg} \mathrm{L}^{-1}$ in the influent to the maximal $6.30 \mathrm{mg} \mathrm{L}^{-1}$ at height of $10 \mathrm{~cm}$, but it decreased slowly to $0.70 \mathrm{mg} \mathrm{L}^{-1}$ in the effluent. The same change rules of $\mathrm{NO}_{2}{ }^{-}-\mathrm{N}$ were observed in the unplanted CW-MFC, but the concentration of $\mathrm{NO}_{2}{ }^{-}-\mathrm{N}$ in the effluent was slightly higher about $1.56 \mathrm{mg} \mathrm{L}^{-1}$. The change of $\mathrm{NO}_{3}{ }^{-}-\mathrm{N}$ can be divided into four stages in the planted CW-MFC, taking on the trend of rising first, dropping, then rising and dropping, namely, two inverse " $V$ " type curves, and the maximal $\mathrm{NO}_{3}{ }^{-}-\mathrm{N}$ concentrations were $3.5 \mathrm{mg} \mathrm{L}^{-1}$ and $5.7 \mathrm{mg} \mathrm{L}^{-1}$ at the height of $20 \mathrm{~cm}$ and $40 \mathrm{~cm}$, respectively. However, only a flush of $\mathrm{NO}_{3}{ }^{-}-\mathrm{N}$ concentration from $0 \mathrm{mg} \mathrm{L}^{-1}$ to $3.70 \mathrm{mg} \mathrm{L}^{-1}$ was observed in the bottom region in the unplanted CWMFC, and then the concentration gradually decreased to $1.70 \mathrm{~m} \mathrm{~L} \mathrm{~L}^{-1}$ at the height of $30 \mathrm{~cm}$, and it changed little in the top region.

Under aerobic conditions, $\mathrm{NH}_{4}{ }^{+}-\mathrm{N}$ could be oxidated to $\mathrm{NO}_{2}{ }^{-}-\mathrm{N}$ and $\mathrm{NO}_{3}{ }^{-}-\mathrm{N}$ by nitrococcus and nitrobacteria, and the increase in $\mathrm{NO}_{x}{ }^{-}-\mathrm{N}$ concentration (sum of $\mathrm{NO}_{2}{ }^{-}-\mathrm{N}$ and $\mathrm{NO}_{3}{ }^{-}-\mathrm{N}$ ) and the decrease in the $\mathrm{NH}_{4}{ }^{+}-\mathrm{N}$ concentration were significantly correlated with $\mathrm{DO}$ in the bottom region both in the two CW-MFCs $(P<0.01)$. But the increase in $\mathrm{NO}_{x}{ }^{-}-\mathrm{N}$ concentration and the decrease in the $\mathrm{NH}_{4}{ }^{+}-\mathrm{N}$ concentration at height of $30-40 \mathrm{~cm}$ in the planted CW-MFC were generally correlated with DO $(P<0.05)$.

\section{Discussion}

4.1. Comparison of Power Output of the Planted CW-MFC and Unplanted CW-MFC. When Ipomoea aquatica was planted in CW-MFC, the bacteria density in anode and cathode both increased, cathode potential became larger, and anode potential become more negative (Figure 4), thus generating more power. Here, the grown Ipomoea aquatica is generally very important feature because it can improve the catalytic activity of anode and cathode mainly due to the enhancement of the microbial density, activity, and diversity in the plant's rhizosphere [28]. Furthermore, root exudates that comprise carbohydrates, carboxylic acids, and amino acids are highly degradable to microorganisms and the most responsible for electron donation [29]. In addition, the internal resistance of the planted CW-MFC accounted for only $61 \%$ of the unplanted CW-MFC, and the cause of such difference may lie in the quantity of current-producing bacteria (such as G. sulfurreducens and Betaproteobacteria), which are able to generate electrically conductive pili or nanowires that assist the microorganism in reaching more distant electrodes. The power densities in the two CW-MFCs were consistent with the change of the internal resistances. It is generally known that the maximum power output occurs when the internal 


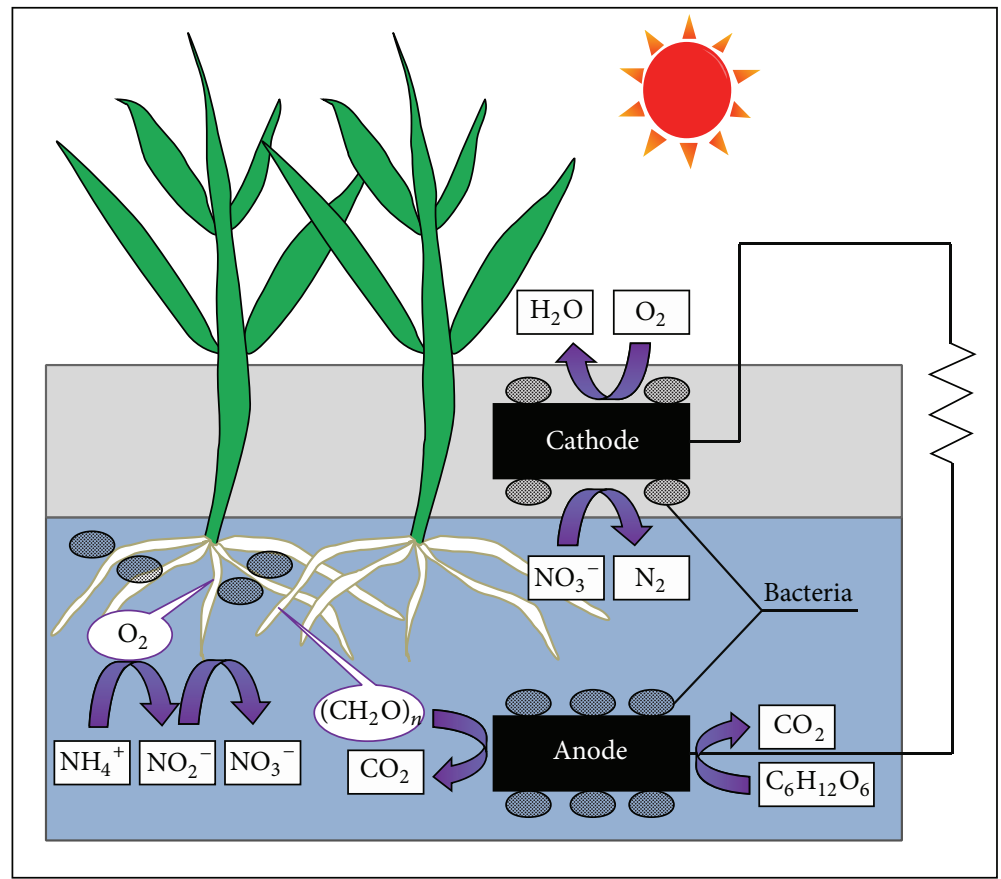

FIGURE 8: The principal reactions for the overall process of the CW-MFC. (1) Plant roots secrete $\mathrm{O}_{2}$ and $\left(\mathrm{CH}_{2} \mathrm{O}\right)_{n}$. (2) Electrons are produced at the anode from the anaerobic degradation of $\left(\mathrm{CH}_{2} \mathrm{O}\right)_{n}$ and $\mathrm{C}_{6} \mathrm{H}_{12} \mathrm{O}_{6}$. (3) $\mathrm{NH}_{4}{ }^{+}$was converted to $\mathrm{NO}_{3}{ }^{-}$by Nitrifying bacterias in the rhizosphere. (4) $\mathrm{O}_{2}$ and $\mathrm{NO}_{3}{ }^{-}$were electron acceptors at the cathode.

resistance is equal to external resistance [25]; thus, the decrease in internal resistance is one reason for the improvement in power generation performance for the planted CWMFC. The improvement in power generation for the planted CW-MFC resulted from three different factors: increased biomass in anode and cathode, a decrease in the internal resistance, and more available fuel secreted from plant roots.

4.2. High Nitrogen Removal in the Planted CW-MFC. The removal of nitrogen (including nitrate, nitrite, and ammonia) in MFC has been reported in recent years. In a MFC, nitrate and nitrite can be removed as electron acceptors in the cathode through electrochemical reduction or autotrophic denitrification [30-32]. A high level of ammonia removal from $198 \pm 1$ to $34 \pm 1 \mathrm{mg} \mathrm{L}^{-1}$ (83\% removal) was obtained from swine wastewater in a single-chamber air cathode MFC system [33]. However, subsequent research demonstrated that the removal of ammonia occurred primarily by physicalchemical mechanisms due to ammonia volatilization with conversion of ammonium ion to the more volatile ammonia species as a result of an elevated $\mathrm{pH}$ near the cathode [34]. In this study, effective TN removal efficiency obtained in the planted CW-MFC might be attributed to Ipomoea aquatica uptaking of $\mathrm{NH}_{4}{ }^{+}$or $\mathrm{NO}_{3}{ }^{-}$as their $\mathrm{N}$ source for growth and yield [35]. In this experiment, the influent $\mathrm{N}$ was sufficient and dominated by $\mathrm{NH}_{4}{ }^{+}$. Many researches indicate that aquatic plant roots can release oxygen $\left(\mathrm{O}_{2}\right)$ in constructed wetland [36, 37]; thus, the rhizosphere was aerated and the nitrification process was promoted by microbial activity, and the $\mathrm{NH}_{4}{ }^{+}$was converted into $\mathrm{NO}_{3}{ }^{-}$via $\mathrm{NO}_{2}{ }^{-}$by the ammonia oxidizing bacteria and nitrite oxidizing [38], whereas the produced $\mathrm{NO}_{3}{ }^{-}\left(E^{\prime \theta} \mathrm{NO}_{3} / \mathrm{N}_{2}=0.74 \mathrm{~V}\right)$ could be used as the final electron acceptor in the cathode (Figure 8). Although the electric production of MFC with nitrate as electron acceptor is inferior to other types of MFC (e.g., $\mathrm{O}_{2}$ as the electron acceptor), realizing the biological denitrification in the cathode is crucial and significant for the total nitrogen removal in the CW-MFC system.

4.3. Comparison of the Planted CW-MFC with Similar Published MFCs. Because of the alternating phases of light and dark, the electric output generated from plant photosynthetic products may show diurnal oscillations with clear fluctuations between the trough and the peak values [39, 40]. Similarly, in this study, the voltage outputs of the planted CWMFC were cyclically fluctuant depended on the day/night cycle. In the planted CW-MFC system, the fuel source consisted of glucose fed from waste water and a certain amount of organic compounds released by Ipomoea aquatica roots (Figure 8). Generally, the photosynthates produced during the day may have led to increased exudates production availability for the anode in the planted CW-MFC. When operated in the light, the CW-MFC could use photosynthates and glucose as fuel generating more electricity. Moreover, roots of Ipomoea aquatica $(20 \pm 2 \mathrm{~cm}$ length but most distributed in the upper part) released more oxygen in the day and created more suitable aerobic conditions in the cathode zone, which induced the improvement of electric output. So the high peak voltages for the planted CW-MFC in the day were attributed to sufficient fuel available in the anode and favorable oxygen condition in the cathode. 
The CW-MFC system can utilize the organic substrate in the influent and plant photosynthate as fuels, so its power output could be divided into two parts: power yield from $\mathrm{COD}_{R}$ in the water body and power transformation from plant photosynthesis. In current study, the maximum power output for the planted CW-MFC was $3.92 \mathrm{GJ} \mathrm{ha}^{-1}$ year $^{-1}\left(12.42 \mathrm{~mW} \mathrm{~m}^{-2}\right)$, the maximum power yield from $\mathrm{COD}_{R}$ in the water body was $66.05 \mathrm{KJ} \mathrm{Kg}^{-1} \mathrm{COD}_{R}$, and the maximum power transformation from plant photosynthesis was $2.31 \mathrm{GJ} \mathrm{ha}^{-1}$ year $^{-1}$. A maximum power density of $15.73 \mathrm{~mW} \mathrm{~m}^{-2}$ for a CW-MFC system planted with canna indica was achieved during the treatment of wastewater containing $1000 \mathrm{mg} \mathrm{L}^{-1}$ methylene blue [18], and it was about $26 \%$ higher than that generated in this study. Our CW-MFC device is constructed with a large anodic geometric surface area about $706.50 \mathrm{~cm}^{2}$, that is, 17 times higher than the CWMFC planted with canna indica $\left(40.93 \mathrm{~cm}^{2}\right)$; moreover, the substrate concentration $\left(200 \mathrm{mg} \mathrm{L}^{-1}\right.$ glucose) in the influent is relatively low in our CW-MFC, so these differences may make the power density slightly less. Besides, many similar MFCs generated power from plant photosynthate have been reported, and the maximum power outputs vary in different systems, such as $1.89 \mathrm{GJ} \mathrm{ha}^{-1}$ year $^{-1}$ of plantMFC in a rice paddy field [39], 4.55 $\mathrm{GJ} \mathrm{ha}^{-1}$ year $^{-1}$ of ricepaddy MFC [41], $0.41 \mathrm{GJ} \mathrm{ha}^{-1}$ year $^{-1}$ of sediment MFC with a biocathode in the rice rhizosphere [19], 70.01 GJ ha ${ }^{-1}$ year $^{-1}$ of plant MFC planted with Spartina anglica [42], $119.83 \pm$ $5.99 \mathrm{GJ} \mathrm{ha}^{-1}$ year $^{-1}$ of Direct Photosynthetic Plant Fuel Cell by using Lemna minuta duckweed [43], and $0.98 \pm$ $0.06 \mathrm{GJ} \mathrm{ha}^{-1}$ year $^{-1}$ of vascular plant biophotovoltaics planted with Oryza sativa [40]. Through comparison and analysis for the previously reports, the power outputs were mainly affected by plant species, plant area (anode surface area), and internal resistance. As MFC tests have been demonstrated that increasing the anode surface area resulted in a slight increase in volumetric power density [4], there would be a huge drop in area power density if the anode surface area were too large. Our device had relatively large anode surface area $\left(706.50 \mathrm{~cm}^{2}\right)$ and high internal resistance $(156 \Omega)$, so the power output was much lower than some of the plant MFCs (for instance, $119.83 \pm 5.99 \mathrm{GJ} \mathrm{ha}^{-1}$ year $^{-1}$ of Direct Photosynthetic Plant Fuel Cell with anode area only $15.75 \mathrm{~cm}^{2}$ and interresistance $91 \Omega$ ). The current power generated by $\mathrm{CW}$ MFC is not competitive; however, the CW-MFC technology possesses potential advantages in removing contaminants in wastewater and reducing greenhouse gas emission, which will attract attention and may worth applying in the future. In this study, the CW-MFC system operating with cheap GAC anode and cathode with no use of precious metals was low cos and had large volume $(35 \mathrm{~L})$, so its application is more possible in the future.

\section{Conclusions}

Conversion of solar energy into electricity can be fulfilled by coupling wetland plant photosynthesis with the microbial conversion of organics to electricity in CW-MFC system.
The CW-MFC planted with Ipomoea aquatica produced a much higher power than that from unplanted CW-MFC, because plant root can improve electrode activity and provide more organic compounds available for fuel. Moreover, the root of aquatic plants could uptake ammonia nitrogen and part of the pollutants to promote the degradation of contaminants in the wastewater and reduce the greenhouse gas. These results show that developing CW-MFC could provide significant prospects for wastewater treatment and bioenergy recovery. Further studies are necessary to investigate the impact of CW-MFC on the rhizospheric environment and aquatic plant physiology as well as the microbial community.

\section{Acknowledgment}

This work was financially supported by the National Natural Science Foundation of China (Grant no. 21277024).

\section{References}

[1] B. E. Logan and J. M. Regan, "Electricity-producing bacterial communities in microbial fuel cells," Trends in Microbiology, vol. 14, no. 12, pp. 512-518, 2006.

[2] Z. Du, H. Li, and T. Gu, "A state of the art review on microbial fuel cells: a promising technology for wastewater treatment and bioenergy," Biotechnology Advances, vol. 25, no. 5, pp. 464-482, 2007.

[3] D. R. Lovley, "The microbe electric: conversion of organic matter to electricity," Current Opinion in Biotechnology, vol. 19, no. 6, pp. 564-571, 2008.

[4] H. Liu, S. Cheng, L. Huang, and B. E. Logan, "Scale-up of membrane-free single-chamber microbial fuel cells," Journal of Power Sources, vol. 179, no. 1, pp. 274-279, 2008.

[5] J. R. Kim, G. C. Premier, F. R. Hawkes, R. M. Dinsdale, and A. J. Guwy, "Development of a tubular microbial fuel cell (MFC) employing a membrane electrode assembly cathode," Journal of Power Sources, vol. 187, no. 2, pp. 393-399, 2009.

[6] B. Logan, S. Cheng, V. Watson, and G. Estadt, "Graphite fiber brush anodes for increased power production in air-cathode microbial fuel cells," Environmental Science and Technology, vol. 41, no. 9, pp. 3341-3346, 2007.

[7] E. Martin, B. Tartakovsky, and O. Savadogo, "Cathode materials evaluation in microbial fuel cells: a comparison of carbon, $\mathrm{Mn}_{2} \mathrm{O}_{3}, \mathrm{Fe}_{2} \mathrm{O}_{3}$ and platinum materials," Electrochimica Acta, vol. 58, no. 1, pp. 58-66, 2011.

[8] S. Ci, Z. Wen, J. Chen, and Z. He, "Decorating anode with bamboo-like nitrogen-doped carbon nanotubes for microbial fuel cells," Electrochemistry Communications, vol. 14, no. 1, pp. 71-74, 2012.

[9] P. S. Jana, M. Behera, and M. M. Ghangrekar, "Performance comparison of up-flow microbial fuel cells fabricated using proton exchange membrane and earthen cylinder," International Journal of Hydrogen Energy, vol. 35, no. 11, pp. 5681-5686, 2010.

[10] M. Rahimnejad, M. Ghasemi, G. D. Najafpour et al., "Synthesis, characterization and application studies of self-made $\mathrm{Fe}_{3} \mathrm{O}_{4} / \mathrm{PES}$ nanocomposite membranes in microbial fuel cell," Electrochimica Acta, vol. 85, pp. 700-706, 2012.

[11] Z. He, J. Kan, F. Mansfeld, L. T. Angenent, and K. H. Nealson, "Self-sustained phototrophic microbial fuel cells based on 
the synergistic cooperation between photosynthetic microorganisms and heterotrophic bacteria," Environmental Science and Technology, vol. 43, no. 5, pp. 1648-1654, 2009.

[12] K. Nishio, K. Hashimoto, and K. Watanabe, "Light/electricity conversion by a self-organized photosynthetic biofilm in a single-chamber reactor," Applied Microbiology and Biotechnology, vol. 86, no. 3, pp. 957-964, 2010.

[13] R. A. Timmers, D. P. B. T. B. Strik, H. V. M. Hamelers, and C. J. N. Buisman, "Long-term performance of a plant microbial fuel cell with Spartina anglica," Applied Microbiology and Biotechnology, vol. 86, no. 3, pp. 973-981, 2010.

[14] L. Xiao, E. B. Young, J. A. Berges, and Z. He, "Integrated photo-bioelectrochemical system for contaminants removal and bioenergy production," Environmental Science and Technology, vol. 46, no. 20, pp. 11459-11466, 2012.

[15] M. Rosenbaum, Z. He, and L. T. Angenent, "Light energy to bioelectricity: photosynthetic microbial fuel cells," Current Opinion in Biotechnology, vol. 21, no. 3, pp. 259-264, 2010.

[16] M. P. Ciria, M. L. Solano, and P. Soriano, "Role of macrophyte Typha latifolia in a constructed wetland for wastewater treatment and assessment of its potential as a biomass fuel," Biosystems Engineering, vol. 92, no. 4, pp. 535-544, 2005.

[17] X. Li, H. Song, W. Xiang, and L. Wu, "Electricity generation during wastewater treatment by a microbial fuel cell coupled with constructed wetland," Journal of Southeast University, vol. 28, no. 2, pp. 175-178, 2012.

[18] A. K. Yadav, P. Dash, A. Mohanty, R. Abbassi, and B. K. Mishra, "Performance assessment of innovative constructed wetlandmicrobial fuel cell for electricity production and dye removal," Ecological Engineering, vol. 47, no. 0, pp. 126-131, 2012.

[19] Z. Chen, Y. Huang, J. Liang, F. Zhao, and Y. Zhu, "A novel sediment microbial fuel cell with a biocathode in the rice rhizosphere," Bioresource Technology, vol. 108, pp. 55-59, 2012.

[20] R. Wang, V. Baldy, C. Périssol, and N. Korboulewsky, "Influence of plants on microbial activity in a vertical-downflow wetland system treating waste activated sludge with high organic matter concentrations," Journal of Environmental Management, vol. 95, supplement, pp. S158-S164, 2012.

[21] G. Zhang, Q. Zhao, Y. Jiao et al., "Improved performance of microbial fuel cell using combination biocathode of graphite fiber brush and graphite granules," Journal of Power Sources, vol. 196, no. 15, pp. 6036-6041, 2011.

[22] G. Zhang, K. Wang, Q. Zhao, Y. Jiao, and D. Lee, "Effect of cathode types on long-term performance and anode bacterial communities in microbial fuel cells," Bioresource Technology, vol. 118, pp. 249-256, 2012.

[23] H. Richter, M. Lanthier, K. P. Nevin, and D. R. Lovley, "Lack of electricity production by Pelobacter carbinolicus indicates that the capacity for $\mathrm{Fe}$ (III) oxide reduction does not necessarily confer electron transfer ability to fuel cell anodes," Applied and Environmental Microbiology, vol. 73, no. 16, pp. 5347-5353, 2007.

[24] W. Manz, R. Amann, W. Ludwig, M. Wagner, and K. Schleifer, "Phylogenetic oligodeoxynucleotide probes for the major subclasses of proteobacteria: problems and solutions," Systematic and Applied Microbiology, vol. 15, no. 4, pp. 593-600, 1992.

[25] B. E. Logan, B. Hamelers, R. Rozendal et al., "Microbial fuel cells: methodology and technology," Environmental Science and Technology, vol. 40, no. 17, pp. 5181-5192, 2006.

[26] S. V. Raghavulu, S. V. Mohan, R. K. Goud, and P. N. Sarma, "Effect of anodic $\mathrm{pH}$ microenvironment on microbial fuel cell (MFC) performance in concurrence with aerated and ferricyanide catholytes," Electrochemistry Communications, vol. 11, no. 2, pp. 371-375, 2009.

[27] J. C. Wei, P. Liang, X. X. Cao, and X. Huang, "A new insight into potential regulation on growth and power generation of Geobacter sulfurreducens in microbial fuel cells based on energy viewpoint," Environmental Science and Technology, vol. 44, no. 8, pp. 3187-3191, 2010.

[28] R. A. Timmers, M. Rothballer, D. P. B. T. B. Strik et al., "Microbial community structure elucidates performance of Glyceria maxima plant microbial fuel cell," Applied Microbiology and Biotechnology, vol. 94, no. 2, pp. 537-548, 2012.

[29] H. Deng, Z. Chen, and F. Zhao, "Energy from plants and microorganisms: progress in plant-microbial fuel cells," ChemSusChem, vol. 5, no. 6, pp. 1006-1011, 2012.

[30] C. Fang, B. Min, and I. Angelidaki, "Nitrate as an oxidant in the cathode chamber of a microbial fuel cell for both power generation and nutrient removal purposes," Applied Biochemistry and Biotechnology, vol. 164, no. 4, pp. 464-474, 2011.

[31] S. Puig, M. Serra, A. Vilar-Sanz et al., "Autotrophic nitrite removal in the cathode of microbial fuel cells," Bioresource Technology, vol. 102, no. 6, pp. 4462-4467, 2011.

[32] Y. Zhang and I. Angelidaki, "Bioelectrode-based approach for enhancing nitrate and nitrite removal and electricity generation from eutrophic lakes," Water Research, vol. 46, no. 19, pp. 64456453, 2012.

[33] B. Min, J. Kim, S. Oh, J. M. Regan, and B. E. Logan, "Electricity generation from swine wastewater using microbial fuel cells," Water Research, vol. 39, no. 20, pp. 4961-4968, 2005.

[34] J. R. Kim, Y. Zuo, J. M. Regan, and B. E. Logan, "Analysis of ammonia loss mechanisms in microbial fuel cells treating animal wastewater," Biotechnology and Bioengineering, vol. 99, no. 5, pp. 1120-1127, 2008.

[35] X. Zhou, G. Wang, and F. Yang, "Characteristics of growth, nutrient uptake, purification effect of Ipomoea aquatica, Lolium multiflorum, and Sorghum sudanense grown under different nitrogen levels," Desalination, vol. 273, no. 2-3, pp. 366-374, 2011.

[36] F. Yao, G. Shen, X. Li, H. Li, H. Hu, and W. Ni, "A comparative study on the potential of oxygen release by roots of selected wetland plants," Physics and Chemistry of the Earth, vol. 36, no. 9-11, pp. 475-478, 2011.

[37] C. Dong, W. Zhu, Y. Q. Zhao, and M. Gao, "Diurnal fluctuations in root oxygen release rate and dissolved oxygen budget in wetland mesocosm," Desalination, vol. 272, no. 1-3, pp. 254-258, 2011.

[38] J. Wu, J. Zhang, W. Jia et al., "Impact of $\mathrm{COD} / \mathrm{N}$ ratio on nitrous oxide emission from microcosm wetlands and their performance in removing nitrogen from wastewater," Bioresource Technology, vol. 100, no. 12, pp. 2910-2917, 2009.

[39] N. Kaku, N. Yonezawa, Y. Kodama, and K. Watanabe, "Plant/microbe cooperation for electricity generation in a rice paddy field," Applied Microbiology and Biotechnology, vol. 79, no. 1, pp. 43-49, 2008.

[40] P. Bombelli, D. Iyer, S. Covshoff et al., "Comparison of power output by rice (Oryza sativa) and an associated weed (Echinochloa glabrescens) in vascular plant bio-photovoltaic (VPBPV) systems," Applied Microbiology and Biotechnology, vol. 97, no. 1, pp. 429-438, 2013.

[41] K. Takanezawa, K. Nishio, S. Kato, K. Hashimoto, and K. Watanabe, "Factors affecting electric output from rice-paddy microbial fuel cells," Bioscience, Biotechnology and Biochemistry, vol. 74, no. 6, pp. 1271-1273, 2010. 
[42] M. Helder, D. P. B. T. B. Strik, H. V. M. Hamelers, A. J. Kuhn, C. Blok, and C. J. N. Buisman, "Concurrent bio-electricity and biomass production in three plant-microbial fuel cells using Spartina anglica, Arundinella anomala and Arundo donax," Bioresource Technology, vol. 101, no. 10, pp. 3541-3547, 2010.

[43] Y. Hubenova and M. Mitov, "Conversion of solar energy into electricity by using duckweed in direct photosynthetic plant fuel cell," Bioelectrochemistry, vol. 87, pp. 185-191, 2012. 

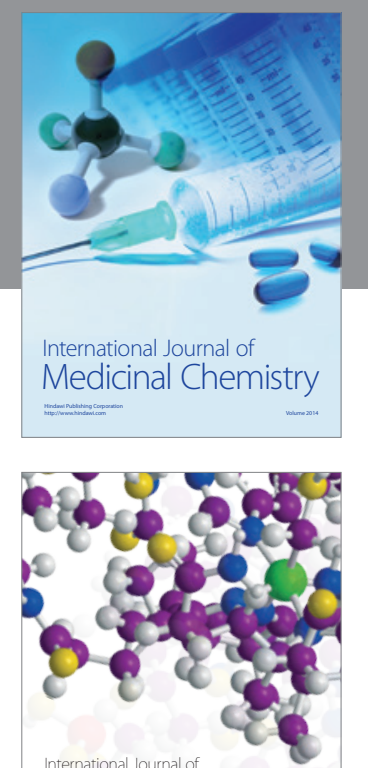

\section{Carbohydrate} Chemistry

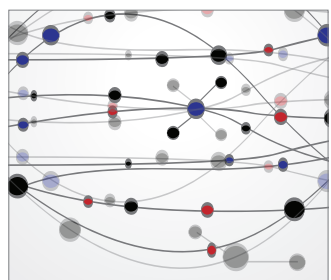

The Scientific World Journal
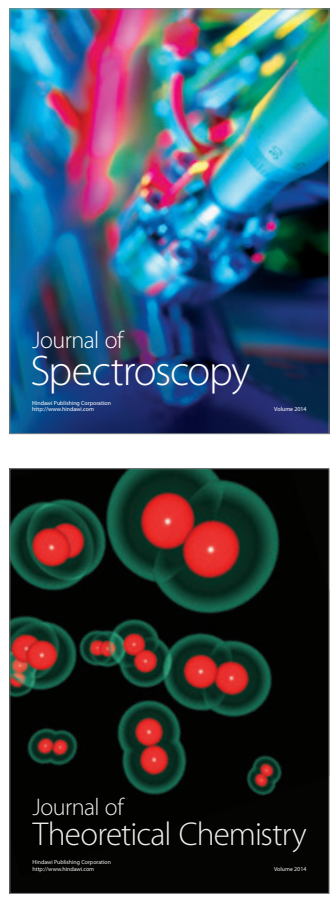
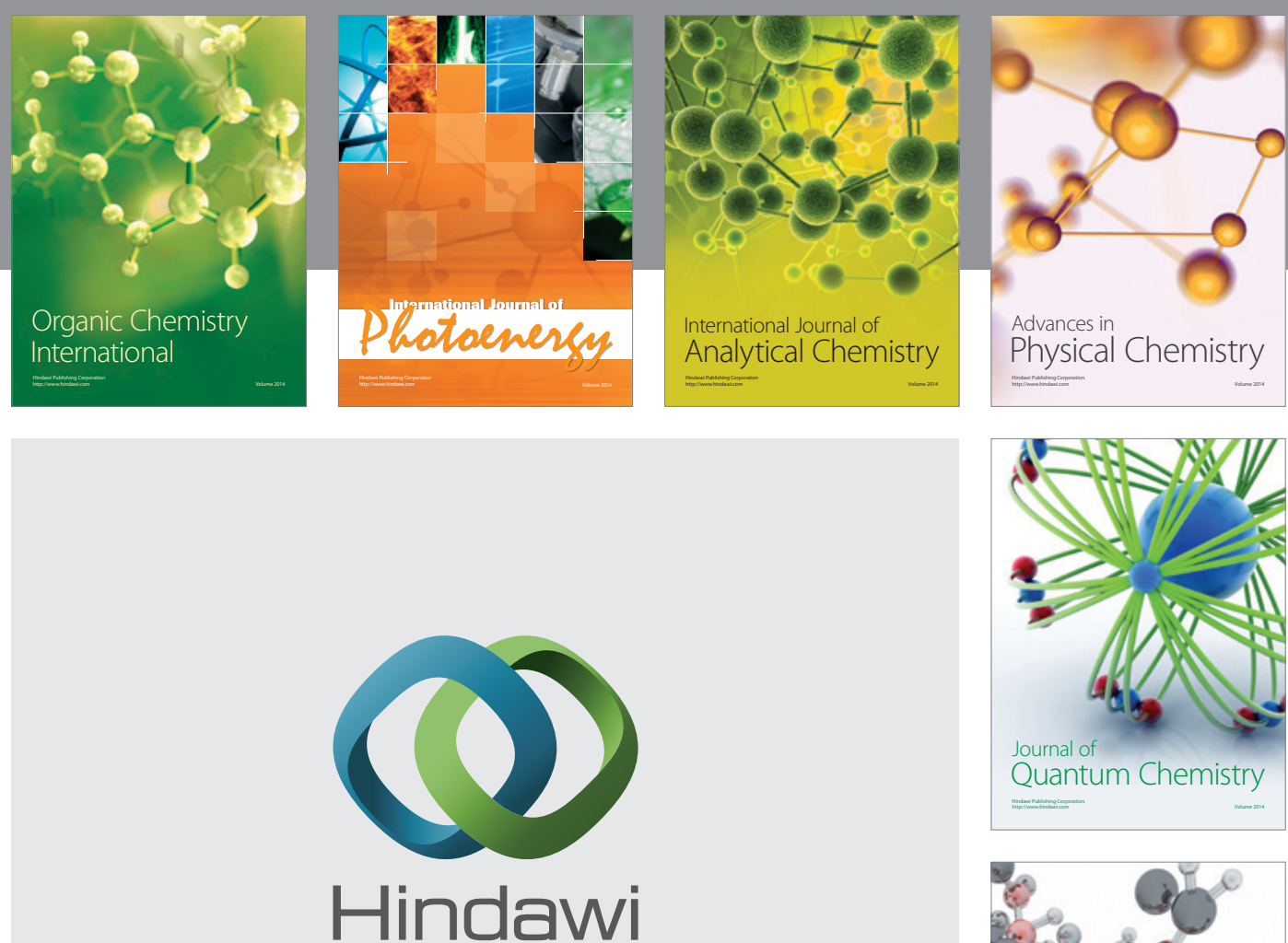

Submit your manuscripts at

http://www.hindawi.com

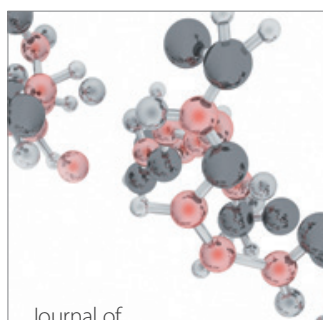

Analytical Methods

in Chemistry

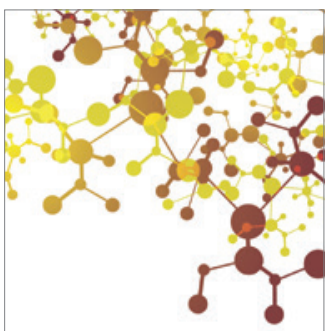

Journal of

Applied Chemistry

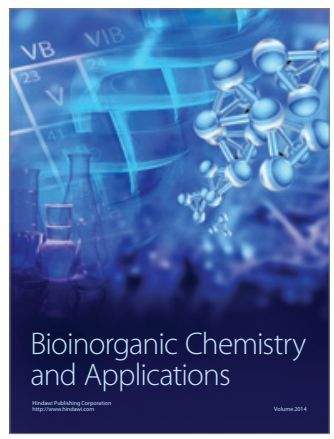

Inorganic Chemistry
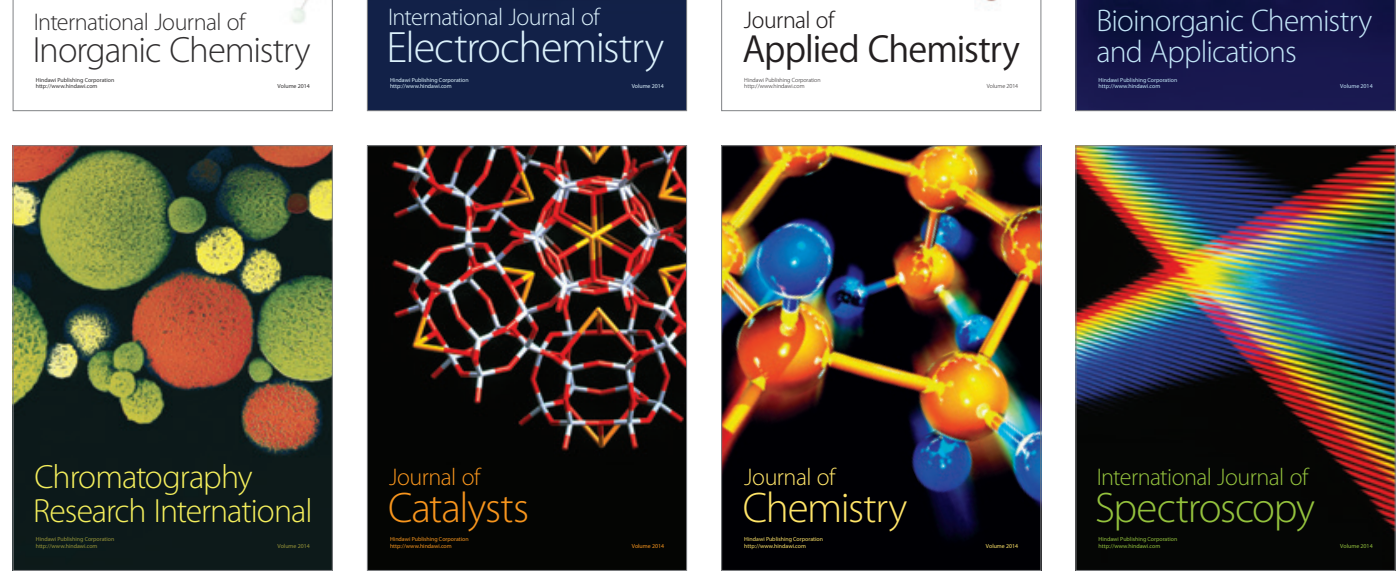